\title{
HARMONISASI HUKUM INTERNASIONAL PADA PRINSIP COMMON BUT DIFFERENTIATED RESPONSIBILITY DALAM HUKUM NASIONAL
}

Oleh:

\author{
Athya \\ Pascasarjana Fakultas Hukum, Universitas Andalas, Padang \\ E-mail: athya.hj@gmail.com
}

\begin{abstract}
Efforts to prevent the growing concentration of GHGs that led to climate change began by the United Nations by establishing a regulation on the protection of the world climate system, first, the Convention on Climate Change is created in 1992. Secondly, Kyoto Protocol was established in 1997. Furthermore, at COP-21 resulted in Paris Agreement. These three arrangements make the Common but Differentiated Responsibility Principle as the basis for protecting the world climate system. This research is to review harmonization of international law on the Common but Differentiated Responsibility Principle in national law. This research uses normative law research. This research is a descriptive analysis with the secondary data obtained. All the data will be analysed qualitatively. Indonesia has implemented an international arrangement to address climate change caused by greenhouse gases into national law by ratifying the UNFCCC by Law Number 6 of 1994 about ratification of UNFCCC and the Kyoto Protocol by Act Number 17 of 2004 about ratification of Kyoto Protocol to the UNFCCC. Indonesia harmonized as a form of implementation of protocol kyoto contents through Law Number 32 of 2009 on Environmental Protection and Management.
\end{abstract}

Keywords: Common but Differentiated Responsibility Principle; Law Harmonization

\begin{abstract}
Abstrak
Upaya untuk mencegah meningkatnya konsentrasi GRK, pertama, Konvensi Perubahan Iklim dibuat tahun 1992. Kedua, didirikan Protokol Kyoto tahun 1997. Selanjutnya, pada COP-21 menghasilkan Perjanjian Paris. Ketiga pengaturan ini menjadikan Prinsip Tanggung Jawab Bersama dengan Tingkat Berbeda-beda sebagai dasar untuk melindungi sistem iklim dunia. Penelitian ini untuk meninjau harmonisasi hukum internasional tentang Prinsip Tanggung Jawab Bersama dengan Tingkat Berbeda-beda dalam hukum nasional. Penelitian ini menggunakan penelitian hukum normatif. Penelitian ini merupakan analisis deskriptif dengan data sekunder yang diperoleh. Semua data akan dianalisis secara kualitatif. Indonesia telah menerapkan pengaturan internasional untuk mengatasi perubahan iklim yang disebabkan oleh gas rumah kaca ke dalam hukum nasional dengan meratifikasi UNFCCC dengan Undang-Undang Nomor 6 Tahun 1994 tentang Pengesahan UNFCCC dan Protokol Kyoto oleh Undang-undang Nomor 17 Tahun 2004 tentang Pengesahan Protokol Kyoto Atas UNFCCC. Indonesia melakukan harmonisasi sebagai wujud implementasi isi Protokol Kyoto melalui Undang-undang Nomor 32 Tahun 2009 tentang Perlindungan dan Pengelolaan Lingkungan Hidup.
\end{abstract}


Kata kunci: Harmonisasi Hukum, Prinsip Tanggung Jawab Bersama dengan Tingkat yang Berbeda-Beda

\section{A. PENDAHULUAN}

Sudah menjadi hal yang tidak bisa terbantahkan bahwa kerusakan lingkungan hidup di sebuah negara akan mempunyai dampak buruk bagi banyak negara lainnya. Salah satu isu lingkungan hidup yang memberikan pengaruh signifikan terhadap semua komponen kehidupan saat ini adalah mengenai fenomena perubahan iklim yang terjadi melalui produksi gas rumah kaca (GRK). GRK yang dinyatakan paling berkontribusi terhadap gejala perubahan iklim adalah $\mathrm{CO}_{2}, \mathrm{CH}_{4}, \mathrm{~N}_{2} \mathrm{O}, \mathrm{NOX}, \mathrm{CO}, \mathrm{PFC}$ dan $\mathrm{SF}_{6}$. Namun, untuk Indonesia dua gas yang disebut terakhir masih sangat kecil emisinya sehingga tidak diperhitungkan.

Guna mencegah perubahan iklim, PBB melangsungkan Konferensi Internasional pertama yang ditujukan untuk masalah lingkungan yakni Konferensi PBB 1972 tentang Lingkungan Hidup Manusia (Stockholm Conference). Konferensi ini berlangsung di Stockholm tanggal 15-16 Juni 1972 sesuai dengan Resolusi tanggal 3 Desember 1968 dari Majelis Umum PBB. ${ }^{1}$ Selanjutnya pada tanggal 3-14 Juni 1992 di Rio de Jeneiro diadakan Konferensi Tingkat Tinggi Bumi (Earth Summit) tentang Lingkungan dan Pembangunan yang lebih dikenal dengan nama United Nations Conference on Environment and Development (UNCED). ${ }^{2}$ Dalam Konferensi Lingkungan Hidup dan Pembangunan PBB di Rio de Jeneiro menghasilkan Deklarasi Rio 1992 sebagai penegasan dari Deklarasi Stockholm 1972. ${ }^{3}$ Dalam KTT inilah kemudian dirumuskan sebuah prinsip yang dikenal sebagai prinsip common but differentiated responsibility.

Melalui KTT Bumi di Rio de Janeiro, Brazil, diagendakan gagasan dan program untuk menekan emisi karbon GRK sebagai penyebab utama perubahan iklim secara internasional yang melahirkan kesepakatan tentang Konvensi Perubahan Iklim pada tahun 1992 dengan tujuan untuk menstabilisasi konsentrasi gas-gas rumah kaca di atmosfer pada tingkat yang tidak membahayakan sistem

1 J.G. Starke, 1989, Pengantar Hukum Internasional Edisi Kesepuluh Jilid 2, Sinar Grafika, Jakarta, hlm. 539.

2 Siti Sundari Rangkuti, 2005, Hukum Lingkungan dan Kebijaksanaan Lingkungan Nasional, Airlangga University Press, Surabaya, hlm. 52.

3 Ida Bagus Wyasa Putra, 2003, Hukum Lingkungan Internasional, PT Refika Aditama, Bandung, hlm. 40. 
iklim dunia. ${ }^{4}$ Konvensi Perubahan Iklim berkekuatan hukum dan berlaku setelah diratifikasi 50 negara sejak 21 Maret $1994 .^{5}$ Kemudian UNFCCC membentuk badan pertemuan tahunan yang disebut Conference of the Parties (COP). Konvensi Perubahan Iklim menetapkan dua prinsip untuk membimbing para pihak dalam mencapai tujuan Konvensi dan dalam menerapkan pasal-pasalnya, diantaranya Prinsip Tanggung Jawab Bersama dengan Tingkat yang Berbedabeda (Common But Differentiated Responsibility) dan Prinsip Kehati-hatian (Precautionary Principle).

Prinsip CBDR meminta pertanggungjawaban yang lebih besar kepada negara-negara industri maju yang dinilai mempunyai kontribusi yang besar dalam kerusakan lingkungan. Menurut perspektif negara maju, salah satu penyebab kegagalan usaha untuk memperbaiki kondisi iklim sebagaimana yang terdapat dalam amanat Protokol Kyoto dihasilkan dari lemahnya peran negara berkembang dalam usaha mitigasi. ${ }^{6}$

Konvensi Perubahan Iklim merupakan konvensi kerangka kerja (framework convention), maka membutuhkan pembentukan protokol untuk menetapkan standar regulasi (regulatory measures). Oleh karena itu, Konvensi Perubahan Iklim menetapkan bahwa COP dapat membuat protokol untuk melaksanakan ketentuanketentuan dari Konvensi Perubahan Iklim dan membuat amandemen terhadap kewajiban para pihak. ${ }^{7}$ Pertemuan COP-3 yang berlangsung di Kyoto, Jepang, pada Desember 1997 menghasilkan kesepakatan Protokol Kyoto yang mengatur sistem pengurangan emisi dan mengikat para pihak negara industri secara hukum untuk melaksanakan upaya penurunan emisi gas rumah kaca yang dapat dilakukan secara individu atau bersama-sama.

Berdasarkan prinsip CBDR, Protokol Kyoto disusun untuk mengatur target kuantitatif penurunan emisi dan target waktu penurunan bagi negara maju. Sementara negara berkembang tidak memiliki kewajiban atau komitmen untuk

4 Kementerian Lingkungan Hidup, 2012, Buku I Pedoman Penyelenggaraan Inventarisasi Gas Rumah Kaca Nasional, hlm. 1.

5 Climate Change Secretariat, 2006: 16-20. Lihat juga United Nations Department of Public Information, February 1997.

6 Deni Bram, 2016, Hukum Perubahan Iklim Perspektif Global dan Nasional, Setara Press, Malang, hlm. 13.

7 Sukanda Husin, 2016, Hukum Internasional dan Indonesia tentang Perubahan Iklim, PT RajaGrafindo Persada, Jakarta, hlm. 7. 
menurunkan emisinya. ${ }^{8}$ Selain itu, Protokol Kyoto adalah satu-satunya protokol yang dipakai untuk mengimplementasikan Konvensi Perubahan Iklim 1992. ${ }^{9}$

Selanjutnya pada COP-21 yang diselenggarakan pada Desember tahun 2015 di Paris yang menghasilkan Perjanjian Paris (Paris Agreement). Perjanjian Paris merupakan kesepakatan yang akan menggantikan Protokol Kyoto dengan tujuan untuk menahan peningkatan temperatur rata-rata global jauh di bawah $2^{\circ} \mathrm{C}$ di atas tingkat di masa pra-industrialisasi dan mewujudkan upaya untuk menekan kenaikan temperatur ke $1,5^{\circ} \mathrm{C}$ di atas tingkat pra-industrialisasi.

Indonesia menjadi salah satu negara yang menyepakati Konvensi Perubahan Iklim pada KTT Bumi di Rio de Janeiro 1992. Sebagai tindak lanjut, Indonesia menerbitkan Undang-Undang No. 6 Tahun 1994 tentang Pengesahan United Nationss Framework Convention on Climate Change dan Undang-undang Nomor 17 Tahun 2004 tentang Pengesahan Kyoto Protocol to The United Nations Framework Convention on Climate Change. Implikasi dari ratifikasi undang-undang ini adalah memperkuat upaya nasional untuk mengantisipasi perubahan iklim baik dari sisi mitigasi maupun adaptasi.

Berdasarkan hal-hal yang telah dikemukakan di atas, untuk saat ini diperlukan kajian terhadap peraturan-peraturan yang telah ada, yaitu mengenai sejauh mana substansi dari masing-masing peraturan tersebut berkesesuaian satu sama lain dan menyusun suatu sistem, yakni regulasi perlindungan sistem iklim dunia yang mengacu pada prinsip CBDR. Dasar pertimbangannya adalah bahwa tanpa adanya harmonisasi dan sinkronisasi peraturan yang menjadi landasan kegiatan perlindungan sistem iklim yang dikeluarkan oleh institusi-institusi sektoral, maka kondisi pengelolaan akan terus berjalan sebagaimana yang terjadi saat ini.

\section{B. METODE PENELITIAN}

Pendekatan masalah yang digunakan dalam penelitian ini adalah penelitian hukum normatif. Data utama yang dijadikan bahan acuan untuk penulisan ini adalah data sekunder. Teknik pengumpulan bahan hukum yang digunakan adalah metode library research (penelitian kepustakaan). Adapun pengolahan dan analisis

8 Daniel Murdiyarso, 2003, Protokol Kyoto Implikasi bagi Negara Berkembang, Kompas, Bogor, hlm. 9.

9 Gatut Susanta dan Hari Sutjahjo, 2007, Akankah Indonesia Tenggelam?, Penebar Plus, Jakarta, hlm. 23. 
data yang digunakan adalah Analisis Kualitatif, yaitu berupa uraian terhadap data yang terkumpul dengan tidak menggunakan angka, sehingga tidak menggunakan rumus statistik tetapi berdasarkan peraturan perundang-undangan, pandangan para pakar hukum, literatur hukum, perjanjian internasional/ konvensi, logika penulis, dan sebagainya.

\section{HASIL DAN PEMBAHASAN}

Sifat semua perjanjian internasional di Indonesia adalah non-self-executing karena untuk dapat diterapkan dalam hukum nasional di Indonesia, perjanjian tersebut harus ditransformasikan suatu tindakan legislatif (impelementing legislation) yang telah diatur dalam aturan hukum di Indonesia. Untuk memberlakukan hukum internasional pada suatu negara menurut doktrin transformasi adalah dengan cara melakukan adopsi khusus (spesific adoption). Adopsi khusus ini memerlukan suatu instrumen ratifikasi dan pembuatan hukum nasional untuk memberikan efek hukum bagi warga negaranya. Inilah yang disebut dengan harmonisasi hukum. ${ }^{10}$

Upaya harmonisasi diperlukan mengingat peraturan perundang-undangan yang berlaku harus disesuaikan dengan berbagai perubahan yang telah terjadi dalam sistem hukum Indonesia, terutama setelah dilakukannya amandemen UUD 1945 yang sangat menentukan arah kebijakan hukum nasional, karena merupakan peraturan perundang-undangan tertinggi dalam hierarki peraturan perundangundangan Indonesia.

Indonesia melakukan pengharmonisasian hukum internasional ke dalam sistem hukum nasionalnya dengan tindakan pencegahan dan penanggulangan dalam rangka perlindungan sistem iklim dengan melakukan upaya adaptasi dan mitigasi perubahan iklim. Indonesia pun telah berusaha semaksimal mungkin dalam mengimplementasikan pengaturan internasional untuk mengatasi perubahan iklim akibat GRK ke dalam hukum nasional Indonesia.

\section{Konvensi Perubahan Iklim}

Dalam hal harmonisasi hukum yang dilakukan Indonesia dalam mengimplementsikan Konvensi Perubahan Iklim 1992 dapat dilihat bahwa

10 Sukanda Husin, 2016, Hukum Internasional dan Indonesia tentang Perubahan Iklim, PT RajaGrafindo Persada, Jakarta, hlm. 21. 
Indonesia pada dasarnya ikut berperan dalam mengatasi isu global mengenai perubahan iklim dengan mengharmonisasikannya kedalam UU Nomor 6 Tahun 1994.

Tabel 1. Harmonisasi Konvensi Perubahan Iklim dengan UU Nomor 6 Tahun 1994 tentang Pengesahan UNFCCC dan Protokol Kyoto

No Konvensi Perubahan UU Nomor 6 Tahun 1994
Iklim 1992

1 Pasal 3 (3); "The parties Untuk mencapai kondisi tersebut berdasarkan should take precautionary Kepmen No.35/MENKLH/ 9/1992 tentang measures to anticipate, Pembentukan Kelompok Kerja Komite prevent or minimize the nasional Iklim dan Lingkungan yang bertujuan causes of climate change untuk meningkatkan kelancaran pelaksanaan and mitigate its adverse tugas-tugas di bidang lingkungan hidup dan effect ...". dampaknya. Lalu Kementerian Lingkungan Hidup kembali membentuk Komisi Nasional dan Tim Teknis Perubahan Iklim (Kepmen No.53 tahun 2003) dalam rangka mengantisipasi perubahan iklim di tingkat nasional dan koordinasi serta kerjasama berbagai pemangku kepentingan.

2 Pasal 3 ayat 4 Indonesia menerbitkan beberapa peraturan menyatakan bahwa adanya keharusan perundang-undangan yang berkaitan dengan memasukkan kebijakan lingkungan hidup sebagai berikut.

pembangunan 1. Undang-undang No. 5 tahun 1990 tentang berkelanjutan untuk Ekosistemnya melindungi sistem iklim ke dalam perencanaan 2. Undang-undang No. 6 Tahun 1994 tentang program pembangunan Pengesahan United Nations Framework Convention On Climate Change (Konvensi nasional. Kerangka Kerja PBB Mengenai Perubahan Iklim)

3. Undang-undang No. 23 Tahun 1997 tentang Pengelolaan Lingkungan Hidup 
4. Undang-undang No. 41 Tahun 1999 tentang Kehutanan

5. Undang-undang No. 7 Tahun 2004 tentang Sumber Daya Air

6. Undang-undang No. 17 Tahun 2004 tentang Pengesahan Kyoto Protocol to the United Nations Framework Convention On Climate Change

7. Undang-undang Republik Indonesia No. 32 Tahun 2009 tentang Perlindungan dan Pengelolaan Lingkungan Hidup

Dengan Indonesia merumuskan kedalam UU No. 6 Tahun 1994, berarti Indonesia telah mengharmonisasikan pasal 3 ayat (4) Konvensi Perubahan Iklim. Dalam hal peratifikasian Konvensi Perubahan Iklim yang dituangkan kedalam undang-undang Indonesia terlihat bahwa teori monisme primat Internasional dianut disini yaitu paham ini beranggapan bahwa hukum nasional bersumber dari hukum internasional.

\section{Protokol Kyoto}

Protokol Kyoto tahun 1997 sudah memuat hard obligations tentang mengurangi gas rumah kaca, karena sudah memuat prinsip baru yakni Common but Differentiated Responsibilities, dan dengan demikian QELROs-nya (Quantified Emissions Limitation and Reduction Objectives) ditetapkan secara berbeda-beda antara negara yang satu dengan yang lain sesuai dengan kemampuan dan tanggungjawabnya. ${ }^{11}$ Berdasarkan prinsip CBDR, Protokol Kyoto tidak membebankan negara berkembang turut serta dalam pengurangan emisi gas rumah kaca. Sedangkan negara maju dan negara ekonominya dalam transisi diharuskan untuk membatasi atau mengurangi emisi gas rumah kaca (greenhouse gases) sampai pada jumlah tertentu. ${ }^{12}$ Adanya pengesahan Protokol Kyoto dengan UU No. 17 Tahun 2004, Indonesia telah meletakkan landasan dan sumber hukum internasional yang berlaku sebagai hukum nasional untuk dijabarkan dalam peraturan perundang-undangan.

11 Sukanda Husin, 2009, Penegakan Hukum Lingkungan di Indonesia, Sinar Grafika, Jakarta, hlm. 28.

12 Sukanda Husin, Op.Cit., hlm. 62. 
Implementasi Protokol Kyoto ke dalam UU No.17 Tahun 2004 lebih spesifik dapat digambarkan dalam tabel sebagai berikut.

Tabel 2. Harmonisasi Protokol Kyoto dalam UU Nomor 17 Tahun 2004 tentang Pengesahan Kyoto Protocol to the United Nations Framework Convention On

Climate Change

\begin{tabular}{|c|c|c|}
\hline No & Protokol Kyoto & UU No. 17 Tahun 2004 \\
\hline \multirow[t]{14}{*}{1} & Pasal 2 (1): & Indonesia memiliki peraturan perundang- \\
\hline & $\begin{array}{l}\text { "Each Party included in Annex I, } \\
\text { in achieving its quantified }\end{array}$ & $\begin{array}{l}\text { undangan yang berkaitan dan } \\
\text { mendukung proses pelaksanaan Protokol }\end{array}$ \\
\hline & $\begin{array}{l}\text { emission limitation and } \\
\text { reduction commitments under }\end{array}$ & $\begin{array}{l}\text { Kyoto. Peraturan perundang-undangan } \\
\text { yang terkait, antara lain sebagai berikut. }\end{array}$ \\
\hline & $\begin{array}{l}\text { Article 3, in order to promote } \\
\text { sustainable development, shall: } \\
\text { Implement and/or further }\end{array}$ & $\begin{array}{l}\text { 1. Undang-undang No. } 11 \text { Tahun } 1967 \\
\text { tentang Ketentuan-ketentuan Pokok } \\
\text { Pertambangan }\end{array}$ \\
\hline & $\begin{array}{l}\text { elaborate policies and measures } \\
\text { in accordance with its national }\end{array}$ & $\begin{array}{l}\text { 2. Undang-undang No. } 5 \text { Tahun } 1990 \\
\text { tentang Konservasi Sumber Daya Alam }\end{array}$ \\
\hline & circumstances ..." & Hayati dan Ekosistemnya \\
\hline & & $\begin{array}{l}\text { 3. Undang-undang No. } 24 \text { Tahun } 1992 \\
\text { tentang Penataan Ruang }\end{array}$ \\
\hline & & $\begin{array}{l}\text { 4. Undang-undang No. } 6 \text { Tahun } 1994 \\
\text { tentang Pengesahan United Nations }\end{array}$ \\
\hline & & Framework Convention on Climate \\
\hline & & Change (Konvensi Kerangka Kerja \\
\hline & & Perserikatan Bangsa-Bangsa tentang \\
\hline & & Perubahan Iklim) \\
\hline & & $\begin{array}{l}\text { 5. Undang-undang No. } 23 \text { Tahun } 1997 \\
\text { tentang Pengelolaan Lingkungan Hidup }\end{array}$ \\
\hline & & $\begin{array}{l}\text { 6. Undang-undang No. } 41 \text { Tahun } 1999 \\
\text { tentang Kehutanan }\end{array}$ \\
\hline 2 & $\begin{array}{l}\text { Pasal } 10 \text { merupakan kewajiban } \\
\text { bersama antara negara industri } \\
\text { yang termasuk pada Annex I }\end{array}$ & $\begin{array}{l}\text { Indonesia sebagai negara Non-Annex I } \\
\text { tidak wajib melakukan hal ini, tetapi dapat } \\
\text { berpartisipasi secara sukarela untuk ikut }\end{array}$ \\
\hline & dengan $r$ & mengurangi emisi karbon di dunia \\
\hline
\end{tabular}


disesuaikan dengan prinsip tanggung jawab bersama yang dibedakan.

3 Pasal 12 merupakan prosedur penurunan emisi GRK dalam rangka kerja sama negara industri dengan negara berkembang untuk mencapai pembangunan berkelanjutan dan berkontribusi dalam mencapai tujuan akhir konvensi.

4 Pasal 13; Lembaga-lembaga yang berfungsi melaksanakan Protokol Kyoto adalah COP/MOP sebagai lembaga tertinggi pengambil keputusan Protokol
Pemerintah Indonesia telah mencanangkan komitmen sukarela yang menyatakan bahwa Indonesia dalam sepuluh tahun mendatang akan menghemat $26 \%$ CO2 atas usaha sendiri. Indonesia secara hukum telah mendukung upaya pencapaian komitmen hukum negara maju dalam penurunan emisinya, terutama dengan kerjasama mitigasi yang dinamakan Mekanisme Pembangunan Bersih (Clean Development Mechanism/ CDM).

Membentuk Designated National Authority (DNA) yaitu Komnas MPB melalui Kepmen LH No. 206 tahun 2005 sehingga secara legal dapat mengikuti MPB dalam upaya menurunkan GRK. DNA merupakan lembaga yang memiliki otoritas memberikan persetujuan proyek MPB dalam bidang ekonomi, sosial, lingkungan, dan teknologi.

Kebijakan Indonesia meratifikasi Protokol Kyoto memberi peluang Indonesia secara ekonomi sebagai negara non-Annex 1 melalui penerapan proyek CDM (Clean Development Mechanism). Indonesia juga mengesahkan pembentukan Komisi Nasional Mekanisme Pembangunan Bersih menjabat sebagai otoritas nasional yang ditunjuk, melalui Keputusan Menteri Lingkungan No. 206 Tahun 2005. Keputusan itu disahkan pada tanggal 21 Juli 2005 sebagai bentuk pelaksanaan teknis dari CDM. ${ }^{13}$

13 Wahyu Yun Santoso dan Andy Omara, 2009, Adopting Green Growth Approach For Climate Change In Indonesia, Asia Law Quarterly, Volume 1, No. 2, hlm. 43. 
Indonesia sebagai salah satu negara yang meratifikasi Protokol Kyoto melakukan harmonisasi sebagai wujud implementasi isi protokol melalui UU No. 32 Tahun 2009 tentang Perlindungan dan Pengelolaan Lingkungan Hidup. Walaupun tidak serta merta mengadopsi secara utuh ketentuan-ketentuan yang diatur dalam protokol, namun sudah tampak jelas adanya upaya pemerintah melalui kebijakankebijakan terkait perlindungan, pelestarian lingkungan dan pembangunan berkelanjutan sebagai dampak pemanasan global dan perubahan iklim.

Konsekuensi Indonesia meratifikasi Protokol Kyoto adalah dilakukannya harmonisasi Protokol Kyoto melalui UU No. 32 Tahun 2009 tentang Perlindungan dan Pengelolaan Lingkungan Hidup. Mekanisme implementasi Protokol Kyoto tergambar jelas arah dan pelaksanaannya dan lebih spesifik dapat digambarkan dalam tabel sebagai berikut.

Tabel 3. Harmonisasi Protokol Kyoto dalam UU Nomor 32 Tahun 2009 tentang Perlindungan dan Pengelolaan Lingkungan Hidup

\begin{tabular}{cll}
\hline Bentuk Harmonisasi & \multicolumn{1}{c}{ Protokol Kyoto } & UU No. 32 Tahun 2009 \\
\hline Lingkup tujuan & Tujuan Protokol Kyoto & Tujuan yang terkait dengan \\
& mengantisipasi dan & Protokol, tercantum dalam \\
mengurangi dampak & poin b dan e yang isinya: \\
global warming dan & 1. Bahwa pembangunan \\
climate change dengan & ekonomi nasional \\
prinsip pembangunan & sebagaimana diamanatkan \\
berkelanjutan & UUD Republik Indonesia \\
(sustainable & Tahun 1945 \\
development). & diselenggarakan \\
& berdasarkan prinsip \\
& pembangunan \\
& berkelanjutan dan \\
& berwawasan lingkungan. \\
& 2. Bahwa pemanasan global \\
& yang semakin meningkat \\
& mengakibatkan perubahan \\
& iklim sehingga \\
& memperparah penurunan
\end{tabular}




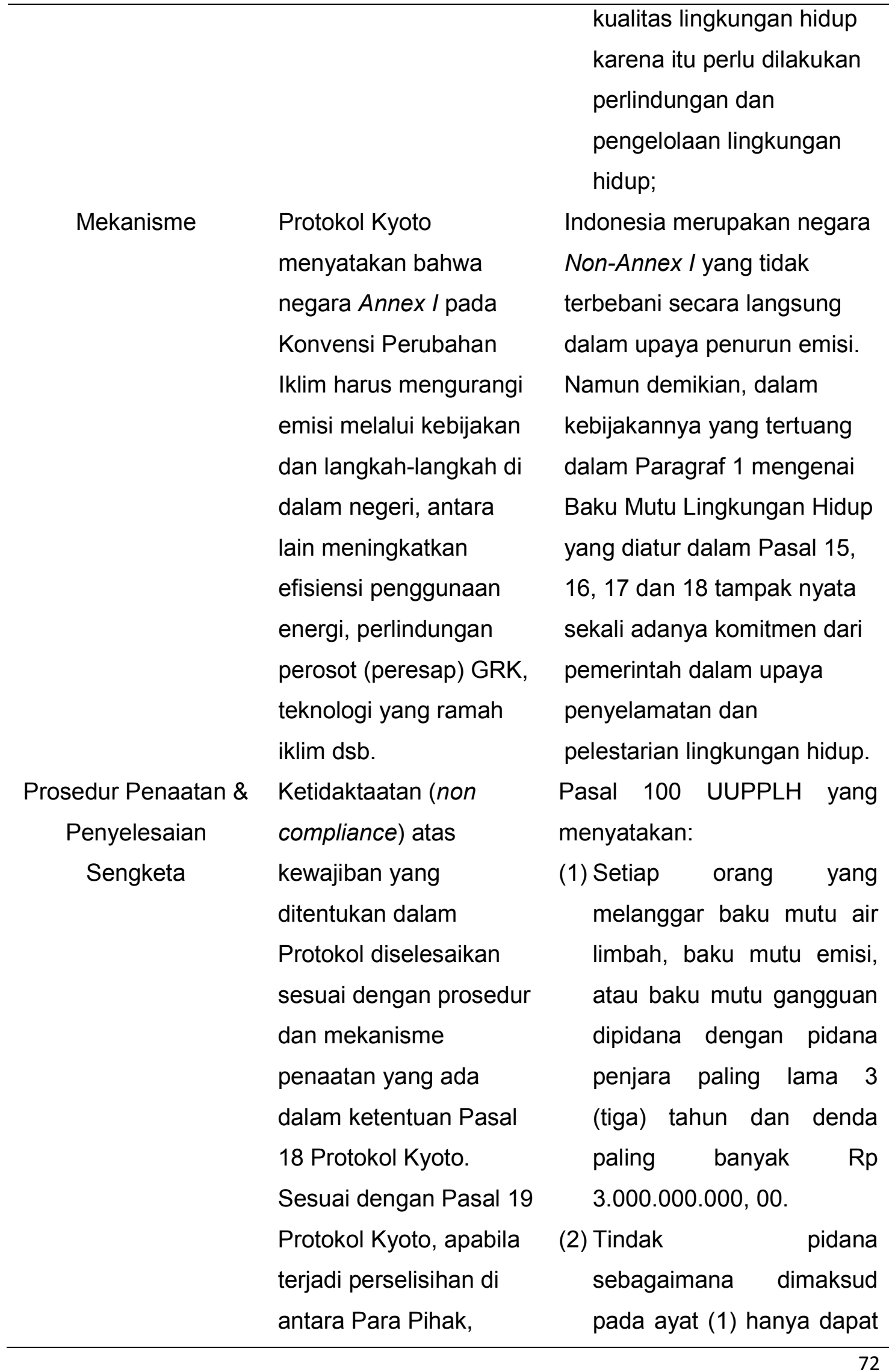




proses penyelesaian
sengketa (dispute
settlement) mengacu
Pasal 14 Konvensi.

proses penyelesaian dikenakan apabila sanksi administratif yang telah dijatuhkan tidak dipatuhi atau pelanggaran dilakukan lebih dari satu kali."

Dari rumusan Pasal 100 ayat

(2) jelas dapat dipahami bahwa sanksi pidana yang tercantum dalam Pasal 100 ayat (1) baru dapat dikenakan jika sanksi administratif tidak efektif atau pelanggaran dilakukan berulang. Hal ini berarti sanksi pidana berfungsi sebagai upaya terakhir.

Walaupun tidak semua ketentuan-ketentuan yang terkandung dalam protokol dapat diharmonisasikan ke dalam hukum nasional, Indonesia sebagai negara pihak peserta konvensi memiliki andil yang cukup baik dalam merespon upaya penyelamatan dan pelestarian lingkungan. Berakhirnya batas waktu yang disepakati dalam pelaksanaan Protokol Kyoto pada tahun 2012 kemarin, dan munculnya ketentuan REDD (Reducing Emission for Degradation Deforestation) sebagai kelanjutan dari protokol tidak menyurutkan Indonesia melakukan upaya penurunan emisi.

Indonesia tetap memiliki komitmen dalam upaya penurunan emisi dan menekan laju gas rumah kaca melalui kebijakan-kebijakan, diantaranya dalam pengelolaan BBM, migrasi bahan bakar minyak ke bahan bakar gas, izin pendirian usaha dan bangunan berbasis AMDAL, menghentikan impor peralatan/produk berbahan freon atau CFC yang menyebabkan kerusakan lapisan ozon bumi dan kebijakan- kebijakan lain terkait upaya penyelamatan lingkungan. ${ }^{14}$

14 Wita Setyaningrum, 2015, Analisis Yuridis Implementasi Protokol Kyoto di Indonesia Sebagai Negara Berkembang, Volume 1, Nomor 2, hlm. 196. 


\section{KESIMPULAN}

Bentuk harmonisasi hukum internasional pada prinsip CBDR dalam hukum nasional Indonesia yang pertama adalah UNFCCC diharmonisasikan melalui Undang-undang Nomor 6 Tahun 1994 tentang Pengesahan UNFCCC. Kedua, Protokol Kyoto diharmonisasikan melalui Undang-undang Nomor 17 Tahun 2004 tentang Pengesahan Protokol Kyoto atas Konvensi Kerangka Kerja Tentang Perubahan Iklim. Ketiga, Indonesia melakukan harmonisasi sebagai wujud implementasi isi protokol kyoto melalui Undang-undang Nomor 32 Tahun 2009 tentang Perlindungan dan Pengelolaan Lingkungan Hidup.

\section{DAFTAR PUSTAKA}

\section{Buku}

Bram, Deni, 2016, Hukum Perubahan Iklim Perspektif Global dan Nasional, Setara Press, Malang.

Husin, Sukanda, 2009, Penegakan Hukum Lingkungan di Indonesia, Sinar Grafika, Jakarta.

Iklim, PT RajaGrafindo Persada, Jakarta.
.,-- 2016, Hukum Internasional dan Tentang Perubahan
-

Murdiyarso, Daniel, 2003, Protokol Kyoto Implikasi bagi Negara Berkembang, Kompas, Bogor.

Putra, Ida Bagus Wyasa, 2003, Hukum Lingkungan Internasional, PT Refika Aditama, Bandung.

Rangkuti, Siti Sundari, 2005, Hukum Lingkungan dan Kebijaksanaan Lingkungan Nasional, Airlangga University Press, Surabaya.

Starke, J.G., 1989, Pengantar Hukum Internasional Edisi Kesepuluh Jilid 2, Sinar Grafika, Jakarta.

Susanta, Gatut dan Sutjahjo, Hari, 2007, Akankah Indonesia Tenggelam?, Penebar Plus, Jakarta.

\section{Sumber Lain}

Climate Change Secretariat, 2006, United Nations Department of Public Information, February 1997.

Kementerian Lingkungan Hidup, 2012, Buku I Pedoman Penyelenggaraan Inventarisasi Gas Rumah Kaca Nasional. 
Santoso, Wahyu Yun dan Omara, Andy, 2009, Adopting Green Growth Approach for Climate Change in Indonesia, Asia Law Quarterly, Volume 1, No. 2.

Setyaningrum, Wita, 2015, Analisis Yuridis Implementasi Protokol Kyoto Di Indonesia Sebagai Negara Berkembang, Volume 1, Nomor 2, diakses dari https://ejournal.undiksha.ac.id pada 28 Mei 2018. 